\title{
EMPOWERMENT ON THE CAPABILITY OF THE BARANGAY TANODS OF MARIA THERESA, CABANATUAN CITY
}

\author{
Odessa G. Lacanilao \\ Faculty, College of Criminology, Nueva Ecija University of Science and Technology
}

Article DOI: https://doi.org/10.36713/epra9128

DOI No: 10.36713/epra9128

\begin{abstract}
This study was conducted to determine on how to empower the capability of the barangay tanods of Maria Theresa, Cabanatuan City. After assessing their level of familiarity on the policing strategies as to Gender-sensitivity and Childfriendly approaches, the researcher proposed some programs on how to empower them. The researcher used a descriptive design of methodology. The outcome of the study have manifested that the barangay tanods have limited knowledge on the process in dealing with victims of violence against women. Further, as to child-friendly approach, the respondents were likewise slightly familiar on the proper treatment in handling child in conflict with the law. As a result, there is a need to empower the capability of the barangay tanods in performing their duties especially on how to become a Gender-sensitive and child-friendly barangay tanod.
\end{abstract}

KEYWORDS: Empowerment, Capability, Barangay Tanod, Gender-Sensitivity Approach, Child-Friendly Approach, Maria Theresa

\section{INTRODUCTION}

Barangay Tanods, being the front liners, play a vital role of keeping the peace and order in every barangay. They are composed of civilian volunteers who protect the community. Barangay Tanod Brigades were organized to assist the government in the maintenance of peace and order in the country. In accordance to such duty, they conduct nightly patrols wherein their lives are exposed to danger in the hands of criminal elements and other perverse members of society.

Under House Bill No. 5438, Barangay Tanods can be considered as the lowest level of Law Enforcement officer in the Philippines. They are front liners in the preparation and response to any type of atrocities, public disorders, emergencies and even disasters or man-made calamities. However, common experience would show that the roles that barangay tanods play go far beyond what is required of them officially.
Likewise, barangay tanods duties and responsibilities include assisting barangay officials in crime prevention and promoting public safety. They also support the objectives of the barangay in compliance with the law as well as for the protection of women and their children against violence.

Further, the barangay government is also given considerable autonomy to manage its own affairs, as well as to explore any possibilities. In order to fulfill the barangay mandates and functions as contained in the Local Government Code, the barangays must be equipped with the necessary competencies (Cadorna, 2008). In order for the barangay tanods to be fully competent, their skills and knowledge should be empowered.

Empowerment is a process by which people take control and act in order to overcome obstacles. The roles of the barangay tanods in running the barangay is indispensable since they aid in other fields such as conflict resolution, peacekeeper, watchman and amongst many others. 
The objective of this study is to empower the capability of the barangay tanods of Maria Theresa, Cabanatuan City. It also attempts to determine the level of familiarity of the respondents with regard to the policing strategies as to Gender-sensitivity and Child-friendly approaches. After assessing the respondents familiarity with the policing strategies, proposed programs or activities on how to empower the barangay tanods will be given.

Furthermore, the researcher as a faculty member of the Nueva Ecija University of Science and Technology believes that this study will help the university, specifically to the College of Criminology. The findings of this study will serve as inputs for the department's initiative to come up with an extension program.

\section{METHODOLOGY}

The descriptive design was used in this study to answer the above-mentioned questions. A descriptive research is used to describe characteristics of a population or phenomenon being studied. It does not answer questions about how/when/why the characteristics occurred. Rather it addresses the "what" question. The respondents of this study were the barangay tanods of Maria Theresa. A questionnairechecklist was used. The statistical used were frequency and percentage distribution.

\section{RESULTS AND DISCUSSIONS}

\subsection{Gender-Sensitivity Approach}

As can be inferred from table 1, with regard to Gender-Sensitivity Approach the; "Respond to GenderBased Violence cases brought to the Barangay and If a third- party reports the incidents of VAWC, follow the correct process for referrals", obtained the highest weighted mean of 3.33. While, "In violence Against Women and their Children (VAWC) cases, inform the victim survivor of her rights, the solution and remedies available to them and the processes involved in her quest for justice", obtained the lowest weighted mean of 1.83 .

Gender-based violence is defined as violence directed against an individual based on sex or gender, which results in psychological, physical or sexual trauma, either directly or indirectly (Belay et al., 2020). Everyone can be a victim regardless of an individual's social status and financial condition. It is also one of the most universal untold human rights violations.

Local Government Units play a very important role in understanding, preventing and addressing violence committed against women since they are the ones working directly with the people in the community. A Gender-Responsive Local Governance is needed to make Violence Against Women (VAW) mechanisms work for their women constituents (Philippine Commission on Women, 2012).

The Implementing Rules and Regulations of the Magna Carta of Women provides for the establishment of a Violence Against Women (VAW) desk in every barangay. The barangay officer will inform the victim of her legal remedies such as filing a case against the abuser and obtaining a Barangay Protection.

The Barangay's adherence with the law is highly important to be given attention. Significantly, barangay is the first level of the government, within the authority of every municipality.

Since Violence Against Women (VAW) transpired in every typical community, and the Barangay as considered to be the nearest unit of the government to the locale of Violence Against Women Cases, it is the most suitable to provide prompt assistance. As such, it is very imperative that the Barangay Officials and Barangay tanods as first responders should be familiarize with the different laws for the protection of women and against violence.

TABLE I. GENDER-SENSITIVITY APPROACH

\begin{tabular}{|c|c|c|}
\hline Indicator & Wm & $\begin{array}{c}\text { Verbal } \\
\text { Interpretation }\end{array}$ \\
\hline 1. Respond to gender-based violence cases brought to the barangay. & 3.33 & Moderately Familiar \\
\hline $\begin{array}{l}\text { 2. Properly conduct interview with the Violence Against Women (VAW) } \\
\text { victim. }\end{array}$ & 2.91 & Moderately Familiar \\
\hline $\begin{array}{l}\text { 3. Ask questions to the victim when she seems hesitant or does not know how } \\
\text { to start the story. }\end{array}$ & 3.16 & Moderately \\
\hline $\begin{array}{l}\text { 4. Secure the victim in a safe place away from the place where the incident } \\
\text { happened. }\end{array}$ & 3.16 & Moderatel \\
\hline $\begin{array}{l}\text { 5. Immediately call the Local Social Welfare and Development Officer } \\
\text { (LSWDO) to report Violence Against Women Cases (VAWC). }\end{array}$ & 3 & Moderately Familiar \\
\hline $\begin{array}{l}\text { 6. If a third-party reports the incident of VAWC, follow the correct process } \\
\text { for referrals. }\end{array}$ & 3.33 & Moderately Familiar \\
\hline
\end{tabular}




\begin{tabular}{|c|c|c|}
\hline $\begin{array}{l}\text { 7. In Violence Against Women and their children (VAWC) cases, inform the } \\
\text { victim-survivor of her rights, the solution and remedies available to to her } \\
\text { and the processes involved in her quest for justice. }\end{array}$ & 1.83 & Slightly Familiar \\
\hline
\end{tabular}

\subsection{Child-Friendly Approach}

As reflected in table II, with regard to the Child-Friendly approach, "Enter the report in a separate blotter exclusively for child abuse and domestic violence cases and kept it confidential at all times" obtained the highest weighted mean of 3.16. While, "Refrain from using vulgar or profane words, and refrain from sexually harassing or abusing or making sexual advances on the child in conflict with the law, obtained the lowest weighted mean of 1.41.

In managing cases of Children in Conflict with the Law and Children at risk, the barangay officials and barangay tanods should be familiar with the Protocols in dealing with such cases or situations. With the release of Barangay Protocol, barangay officials are look forward to handle child-related cases more efficiently. Correspondingly, the practice in some barangays is to assign the child in conflict with the law a code number to keep the identity of the child confidential.

Apart from barangay officials, the Barangay Protocol is regarded as helpful to any barangay committee or appointed volunteer engaged in child protection; barangay tanods; and members of the barangay council for the protection of children.

Further, once a child is taken into custody by the barangay because the child is accused of having committed as offense under the Philippine Law, the child is already considered a Child in Conflict with the Law. In dealing with juvenile delinquents one must treat a juvenile as a person and should try to penetrate into the juveniles mind rather than keeping them behind cold walls (Mousavi et al., 2016).

Likewise, as stated in the Barangay Protocol in managing cases of children in conflict with the law and children at risk; the use of instruments of force or restraint, unnecessary violence or force, vulgar language, sexual advances on child, torture and harassment or abuse of child are acts which are strictly prohibited when taking custody of the child.

The barangay plays a significant role in handling Child in Conflict with the law. The barangay officials and barangay tanods being front liners of public service, they are the ones who must be judicious and have a sufficient knowledge to attend to the challenges and needs of child in conflict with the law.

TABLE II. CHILD-FRIENDLY APPROACH

\begin{tabular}{|c|c|c|}
\hline INDICATOR & WM & $\begin{array}{c}\text { VERBAL } \\
\text { DESCRIPTION }\end{array}$ \\
\hline $\begin{array}{l}\text { 1. Enter the report in a separate blotter exclusively for child abuse and } \\
\text { domestic violence cases and kept it confidential at all times. }\end{array}$ & 3.16 & $\begin{array}{l}\text { Moderately } \\
\text { Familiar }\end{array}$ \\
\hline $\begin{array}{l}\text { 2. If the report is made by a child victim, interview the child regarding } \\
\text { his/her personal circumstances and refer him/her immediately to the } \\
\text { proper medical and health officer for a thorough physical and medical } \\
\text { examination. }\end{array}$ & 1.66 & Slightly Familiar \\
\hline $\begin{array}{l}\text { 3. Immediately, but not, later than eight (8) hours after apprehension, turn } \\
\text { over custody of the child to the Social Welfare and Development Office } \\
\text { or other NGO's and notify the child's parents/guardians and Public } \\
\text { Attorney's Office of the child's apprehension. }\end{array}$ & 2.83 & $\begin{array}{l}\text { Moderately } \\
\text { Familiar }\end{array}$ \\
\hline $\begin{array}{l}\text { 4. When a child reports incest or abuse by guardians, notifying the parents } \\
\text { or guardians should be left to the sound judgment of DSWD/LSWDO. }\end{array}$ & 2.5 & $\begin{array}{l}\text { Moderately } \\
\text { Familiar }\end{array}$ \\
\hline $\begin{array}{l}\text { 5. Refrain from using vulgar or profane words and from sexually harassing } \\
\text { or abusing or making sexual advances on the child in conflict with the } \\
\text { law. }\end{array}$ & 1.41 & Slightly Familiar \\
\hline $\begin{array}{l}\text { 6. Avoid displaying or using any firearm weapon, handcuffs or other } \\
\text { instruments of force or restraint unless absolutely necessary to the child } \\
\text { under custody. }\end{array}$ & 2.5 & $\begin{array}{l}\text { Moderately } \\
\text { Familiar }\end{array}$ \\
\hline $\begin{array}{l}\text { 7. Ensure that all statements signed by the child during investigation shall } \\
\text { be witnessed by the child's parents or guardian, social worker, or legal } \\
\text { counsel in attendance who shall affix his/her signature to the said } \\
\text { statement. }\end{array}$ & 2.33 & Slightly Familiar \\
\hline
\end{tabular}




\subsection{Proposed Programs}

The proposed programs or activities were developed in order to empower the capability of the Barangay Tanods of Maria Theresa. As presented in table 3, the proposed activities were constituted of the objectives, proponents, strategies and as well as the beneficiaries of the programs.

TABLE III. Proposed programs or activities

\begin{tabular}{|c|c|c|c|c|}
\hline $\begin{array}{c}\text { PROPOSED } \\
\text { ACTIVITY }\end{array}$ & OBJECTIVES & PROPONENT & STRATEGIES & BENEFICIARIES \\
\hline $\begin{array}{l}\text { Seminar on the } \\
\text { Duties and } \\
\text { Responsibilities of } \\
\text { the Barangay } \\
\text { Tanods }\end{array}$ & $\begin{array}{l}\text { To provide the } \\
\text { Barangay Tanods } \\
\text { with knowledge in } \\
\text { order to familiarize } \\
\text { on their duties and } \\
\text { responsibilities. }\end{array}$ & $\begin{array}{l}\text { Barangay Ma. } \\
\text { Theresa and Nueva } \\
\text { Ecija University of } \\
\text { Science and } \\
\text { Technology }\end{array}$ & $\begin{array}{l}\text { Conduct series of } \\
\text { Trainings /Seminars }\end{array}$ & $\begin{array}{l}\text { Barangay Tanods of } \\
\text { Ma. Theresa, } \\
\text { Cabanatuan City }\end{array}$ \\
\hline $\begin{array}{l}\text { Lecture/Discussion } \\
\text { on Human Relations }\end{array}$ & $\begin{array}{l}\text { To widen the } \\
\text { knowledge/skills of } \\
\text { the Barangay } \\
\text { Tanods on Human } \\
\text { Relations. }\end{array}$ & $\begin{array}{l}\text { Barangay Ma. } \\
\text { Theresa and Nueva } \\
\text { Ecija University of } \\
\text { Science and } \\
\text { Technology }\end{array}$ & $\begin{array}{l}\text { Invite people who } \\
\text { have special skills or } \\
\text { knowledge on the } \\
\text { subject matter who } \\
\text { will serve as } \\
\text { Resource Speakers. }\end{array}$ & $\begin{array}{l}\text { Residents, Barangay } \\
\text { Tanods and officials } \\
\text { of Ma. Theresa, } \\
\text { Cabanatuan City. }\end{array}$ \\
\hline $\begin{array}{l}\text { Seminars/Lectures } \\
\text { on Gender- } \\
\text { Sensitivity Approach } \\
\text { and Child-Friendly } \\
\text { Approach of } \\
\text { Barangay tanods in } \\
\text { the performance of } \\
\text { their duties and } \\
\text { responsibilities }\end{array}$ & $\begin{array}{l}\text { To broaden the } \\
\text { knowledge of the } \\
\text { Barangay tanods on } \\
\text { how to perform their } \\
\text { duties and functions } \\
\text { as a Gender- } \\
\text { Sensitive and Child- } \\
\text { Friendly Barangay } \\
\text { Tanods. }\end{array}$ & $\begin{array}{l}\text { Barangay Ma. } \\
\text { Theresa and Nueva } \\
\text { Ecija University of } \\
\text { Science and } \\
\text { Technology }\end{array}$ & $\begin{array}{l}\text { Invite speakers who } \\
\text { are expert in the } \\
\text { field. }\end{array}$ & $\begin{array}{l}\text { Residents, Barangay } \\
\text { Tanods and officials } \\
\text { of Ma. Theresa, } \\
\text { Cabanatuan City. }\end{array}$ \\
\hline $\begin{array}{l}\text { Workshop/Training } \\
\text { on the procedures of } \\
\text { conducting } \\
\text { Warrantless Arrest. }\end{array}$ & $\begin{array}{l}\text { To enhance the } \\
\text { capability of the } \\
\text { Barangay Tanods } \\
\text { and officials in } \\
\text { conducting } \\
\text { Warrantless Arrest. }\end{array}$ & $\begin{array}{l}\text { Barangay Ma. } \\
\text { Theresa and Nueva } \\
\text { Ecija University of } \\
\text { Science and } \\
\text { Technology }\end{array}$ & $\begin{array}{l}\text { Invite speakers in } \\
\text { the field who will } \\
\text { serve as resource } \\
\text { speakers. }\end{array}$ & $\begin{array}{l}\text { Residents, Barangay } \\
\text { Tanods and officials } \\
\text { of Ma. Theresa, } \\
\text { Cabanatuan City. }\end{array}$ \\
\hline
\end{tabular}

\section{CONCLUSION}

As can be gleaned from the study, it is apparent that the barangay tanods have limited knowledge on the process in dealing with the victims of violence against women. Further, as to child-friendly approach, the respondents were likewise slightly familiar on the proper treatment in handling child in conflict with the law. As a result, programs or activities in order to empower the capability of the barangay tanods in performing their duties especially on how to become a gender-sensitive and child-friendly barangay tanod were proposed.

\section{REFERENCES}

1. Alicar-Cadorna, E. (2008). Productivity and Performance of Barangays: The Case of the Heritage City of Vigan, Philippines. World Academy of Science, Engineering and Technology, International Journal of Social, Behavioral, Educational, Economic, Business and Industrial Engineering, 2, 1206-1218.

2. Habtamu Gebrehana Belay, Tewachew Muche Liyeh, Habtamu Abie Tassew, Abeba Belay Ayalew, Yitayal Ayalew Goshu, Gedefaye Nibret Mihretie, "Magnitude of Gender-Based Violence 
and Its Associated Factors among Female Night Students in Bahir Dar City, Amhara Region, Ethiopia", International Journal of Reproductive Medicine, vol. 2021, Article

ID 6694890, 7 pages, 2021. https://doi.org/10.1155 /2021/6694890

3. Mousavi, Shohreh and Rastegari, Behnam and Nordin, Rohaid, Improving the Legal Protection of Child in Conflict with the Law: Reintegration and Rehabilitation into Society. Indonesia, Malaysia 6th International Conference, 2016, Available at SSRN: https://ssrn.com/abstract $=2779974$ or http:// dx.doi.org/10.2139/ssrn.2779974

4. Barangay VAW Desk Handbook, copyright (C) 2012 Philippine Commission on Women 1145 J.P. Laurel St., San Miguel, Manila, 1105, Philippines Tel. no. (632) - 735-4955, www.pcw.gov.ph, ISBN 978971-8701-12-6

5. Manual on Barangay Protocol in Managing Cases of Children in Conflict with the law and Children at Risk 